\title{
How regional organizations cope with recurrent stress: the case of South America
}

DOI: http://dx.doi.org/10.1590/0034-7329202100206

Revista Brasileira de Política Internacional ISSN 1983-3121

http://www.scielo.br/rbpi

\section{Detlef Nolte ${ }^{1}$}

${ }^{1}$ German Institute for Global and Area Studies (GIGA) - Institute for Latin American Studies, Hamburg, Germany (detlef.nolte@giga-hamburg.de)

ORCID ID: orcid.org/0000-0003-2014-272X

\section{Brigitte Weiffen ${ }^{2}$}

${ }^{2}$ The Open University - Politics and International Studies, Milton Keynes, United Kingdom (brigitte.weiffen@open.ac.uk)

iD ORCID ID:

orcid.org/0000-0003-0341-8704

\section{Copyright:}

- This is an open-access article distributed under the terms of a Creative Commons Attribution License, which permits unrestricted use, distribution, and reproduction in any medium, provided that the original author and source are credited.

- Este é um artigo publicado em acesso aberto e distribuído sob os termos da Licença de Atribuição Creative Commons, que permite uso irrestrito, distribuição e reprodução em qualquer meio, desde que o autor e a fonte originais sejam creditados. 
challenge has amplified disintegrative trends, but also exhibited varying degrees of resilience of regional organizations.

This article studies transformations in regionalism brought about by global, regional, and domestic challenges, which we conceptualize as stress factors, or stressors. It takes stock of different types of stressors facing regions and focuses on the capacity of regional organizations to cope with them. Since these stress factors can affect several regional organizations in the same region at the same time, one can also speak of "regionalism under stress" (Nolte and Weiffen 2021). While individual regional organizations react differently to stress, the synopsis of individual reactions provides an overall picture of a region's resilience to stress.

To build our analytical framework, we draw on psychological research on how individuals respond to stress. Just like an individual, regional organizations are equipped with a varying number of coping resources which make them more or less resilient to stress. Furthermore, we argue that the outcome of one stress situation has feedback effects on the coping resources, in the sense that successes in dealing with stress can strengthen regional organizations' future resilience, whereas failures can set off or intensify trends toward disintegration.

To illustrate these claims, we will focus on stressors for regionalism in Latin America, with a special focus on South America. Latin American regionalism seems to be overstressed. The Union of South American Nations (UNASUR), considered an auspicious integration project after its foundation in 2008, has effectively dissolved, following the announcement in April 2018 by more than half of the member states to suspend their participation. Other Latin and South American regional organizations have also lost momentum, including the Community of Latin American and Caribbean States (CELAC), the Bolivarian Alliance for the Peoples of Our America (ALBA), and to a lesser degree the Andean Community of Nations (CAN) and the Southern Cone Common Market (Mercosur).

The following section identifies stress factors and characteristics of regions that buttress or undermine their capacity to deal with stress, outlines the coping process, and lays out our research design and methodology. The two subsequent sections analyze two stress situations facing South American regionalism: the political crisis in Venezuela and the Covid-19 pandemic. The Venezuelan crisis erupted after President Nicolás Maduro came into office in 2013 and started to repress and curtail the rights of the opposition. Mediation attempts by regional organizations led to ideological standoffs and ushered in the death of UNASUR, leaving the region in a worse starting position when facing the next stress situation. Since 2020, Covid-19 has not only constituted an additional stressor for a changing regional order but has also reinforced other stress factors, such as low rates of economic growth, the emergence of populism with nationalist traits in some countries, and the repercussions of the conflict between the United States and China. The conclusion discusses the implications of our findings for regionalism in South America, and for the crisis of regionalism more broadly. 


\section{Stressors and regional organizations}

While many recent publications explore the crisis of multilateralism, their focus is usually on global organizations or the European Union. Few address the challenges to regionalism outside of Europe, and if they do, they concentrate almost exclusively on the impact of economic and financial crises (Fioramonti 2012; Saurugger and Terpan 2016). Recent publications have also assessed the effects of the Covid-19 pandemic on regional organizations in various regions (e.g., Debre and Dijkstra 2021b; Melo and Papageorgiou 2021). Most existing studies, however, focus on one challenge only, whereas our contribution studies the impact of a sequence of stress situations.

\section{Identifying stressors and region characteristics}

The concept of stressor denotes challenges which, viewed individually, present a policy problem, but which can trigger a crisis if they become more severe, remain on the agenda for a longer period, or if several stressors accumulate and reinforce each other. The geographical origin of stressors can be global, regional, or domestic. We inductively drew on the recent experiences of both Europe and Latin America (with a view to Africa and Southeast Asia) to identify challenges that can become stress factors for regionalism (Weiffen 2021a, 21-24): Economic challenges include economic, financial, monetary, debt, and banking crises that take place on the global, regional, or domestic level. Security challenges arise due to conflict, warfare, and ensuing humanitarian crises within the region or in the neighborhood. Socio-cultural challenges emerge from domestic contestations about identity due to ethnic heterogeneity or a massive influx of immigrants and refugees into the region. Political challenges result from all sorts of political instability in the region, from governments that bend or break democratic norms, as well as from political-ideological preference divergences among governments. Finally, global and regional power shifts pose challenges to the established international order (see Figure 1).

Stressors put regional organizations to the test. It is intuitively plausible that stressors might cause a crisis, exacerbate pre-existing problems, trigger withdrawals from international organizations (IOs) (Von Borzyskowski and Vabulas 2019), or contribute to processes of disintegration. In fact, the mortality of IOs increases in periods of major political and economic changes (Eilstrup-Sangiovanni 2021). On the other hand, neo-functionalists believed that crises are often constructive in nature, in the sense that they result in progress toward more cooperation and integration (Dosenrode 2012). Thus, stress factors might also evoke a counter-reaction, strengthen the resilience of the region, and give new impetus to regional projects. We assume that the impact of stress factors is mediated by characteristics of the region that might provide elements of resilience but might also exacerbate the negative impact of stressors (Weiffen 2021a, 28). Therefore, the same stress factors might have varying effects on regionalism in different regions. 
Figure 1. Stressors meet region characteristics

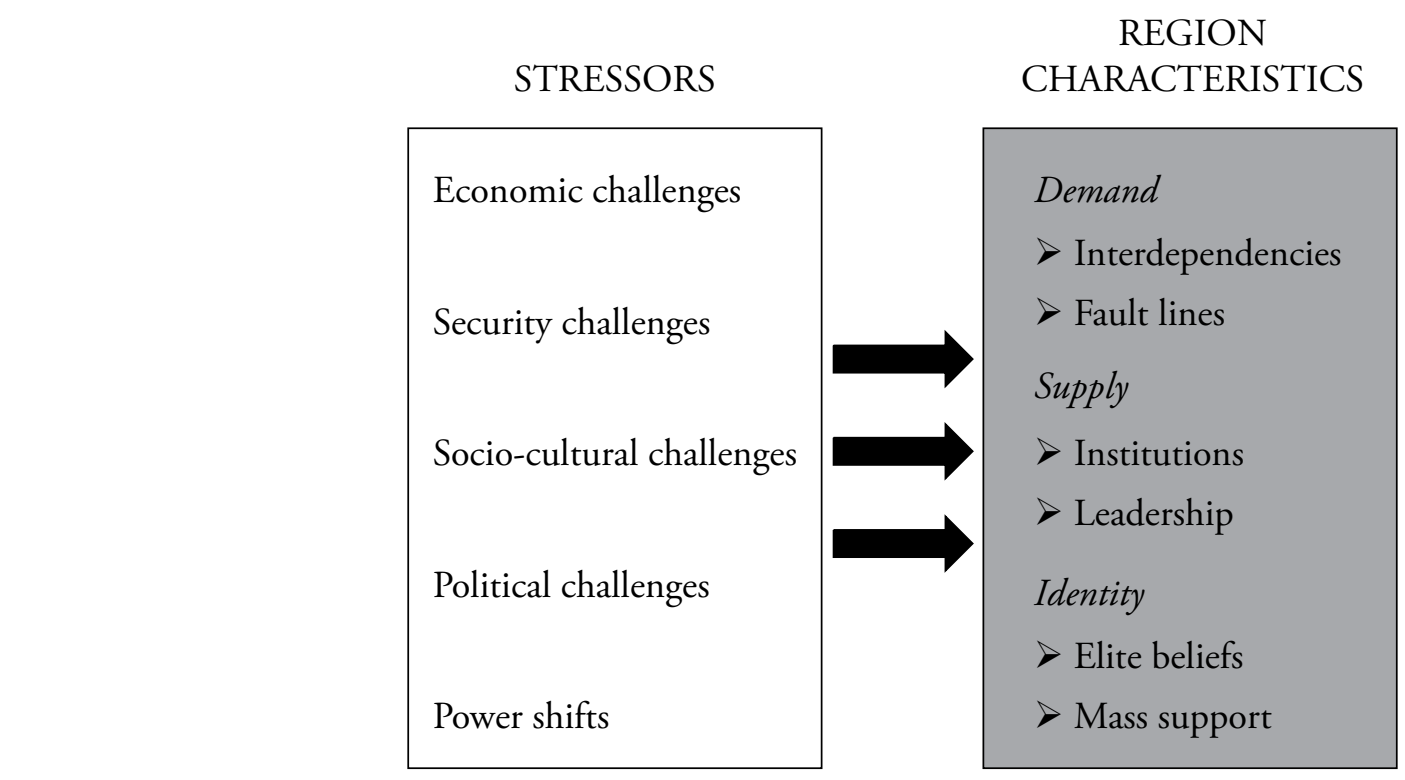

Source: Authors' elaboration, based on Weiffen (2021).

What characteristics make regions resilient and which ones make them more vulnerable and can cause disintegration? Following Börzel and Risse (2021), we divide region characteristics into factors related to demand, supply, and identity (Figure 1). First, regions differ in their degree of regionalization, that is, their economic, political, social, and cultural interconnectedness as expressed in cross-border flows of capital, goods, ideas, and people. A high level of regionalization generally reinforces regionalism as a political project. Economic interdependencies are especially effective in creating a demand for the establishment of regional institutions. In turn, fault lines due to unresolved inter-state conflicts, or ideological antagonism among political regimes tend to present strong obstacles to regional cooperation and integration. Both interdependencies and fault lines influence the demand for regional cooperation and thus enhance or weaken a region's resilience in the face of stress.

Second, while the demand for regional cooperation refers to structural conditions or limitations, the supply side addresses the role of institutions and actors. Resilience might result from the strength, the predominant type, and the density of existing regional institutions that are capable of responding to new challenges. The growing literature on survival (as opposed to death or replacement) of IOs indentifies, among the significant factors, the age of the organization, the technical or political character, the degree of institutionalization, and the strength of the secretariat (Gray 2018; Eilstrup-Sangiovanni 2020; 2021; Debre and Dijkstra 2021a).

Regional leaders and their political will to promote integration and resort to regional institutions as a problem-solving mechanism also play a role. Thus, regionalism's resilience might be strengthened or weakened in accordance with changing foreign policy preferences of regional powers and their leaders. Research on the withdrawal from IOs reveals that the withdrawal of leading states can create a contagion effect inducing further withdrawals (Von Borzyskowski and Vabulas 2019). 
Third, the strength of regional identities among political elites, as manifested in discourses and narratives, can reinforce the resilience of regionalism; even more so if regional discourses and projects resonate with the identities and beliefs of citizens (Weiffen 2021a, 28-29). Altogether, the characteristics of the region act as a filter that either attenuates or increases the impact of stress factors.

\section{How regional organizations cope with stress}

We analyze the impact of stressors on regional organizations in analogy with how individuals cope with stress. The application of psychological perspectives to International Relations (IR) is a growing area of research (Kertzer and Tingley 2018; Gildea 2020). Despite widespread recognition of the utility of incorporating psychological theories and variables, the issue of aggregation is considered problematic: while for psychologists the unit of analysis is the individual, most IR models concern aggregates such as states and international institutions, and it might not be straightforward to transfer individual-level psychological theories to the aggregate level. However, we share Gildea's (2020) view that the disciplinary preoccupation with aggregation in IR may hinder rather than pave the way to a fruitful combination of knowledge from different fields. Research in psychology has aided scholars in their efforts to build theories, identify scope conditions, refine concepts, and put assumptions to the test. We therefore opted for a pragmatic approach which treats aggregate actors as unitary and transfers findings from psychology to construct a new model of aggregate behavior.

In psychology, the term "coping" refers to adaptively changing cognitive and behavioral efforts to manage stress (Lazarus and Folkman 1984, 141). Lazarus' (1999) widely used model of coping with stress is based on the idea of reciprocal interaction between individuals and their environment. Exploring the environment in which stress and coping occur, DeLongis and Holtzman (2005) highlighted three contextual factors that influence the selection, effectiveness and outcomes of certain coping strategies: the nature of the stress situation, the social context in which the situation and the coping occur, and the personality of those involved. The nature of a stress situation includes properties such as novelty, imminence, duration, and uncertainty. Context refers to the timing of the situation in the course of an individual's life cycle and in relation to other (distant, recent, or concurrent) situations. Personality factors have also been framed as "coping resources" and "constraints that inhibit use of these resources" (Lazarus and Folkman 1984, 158ff). 
Figure 2. The coping process

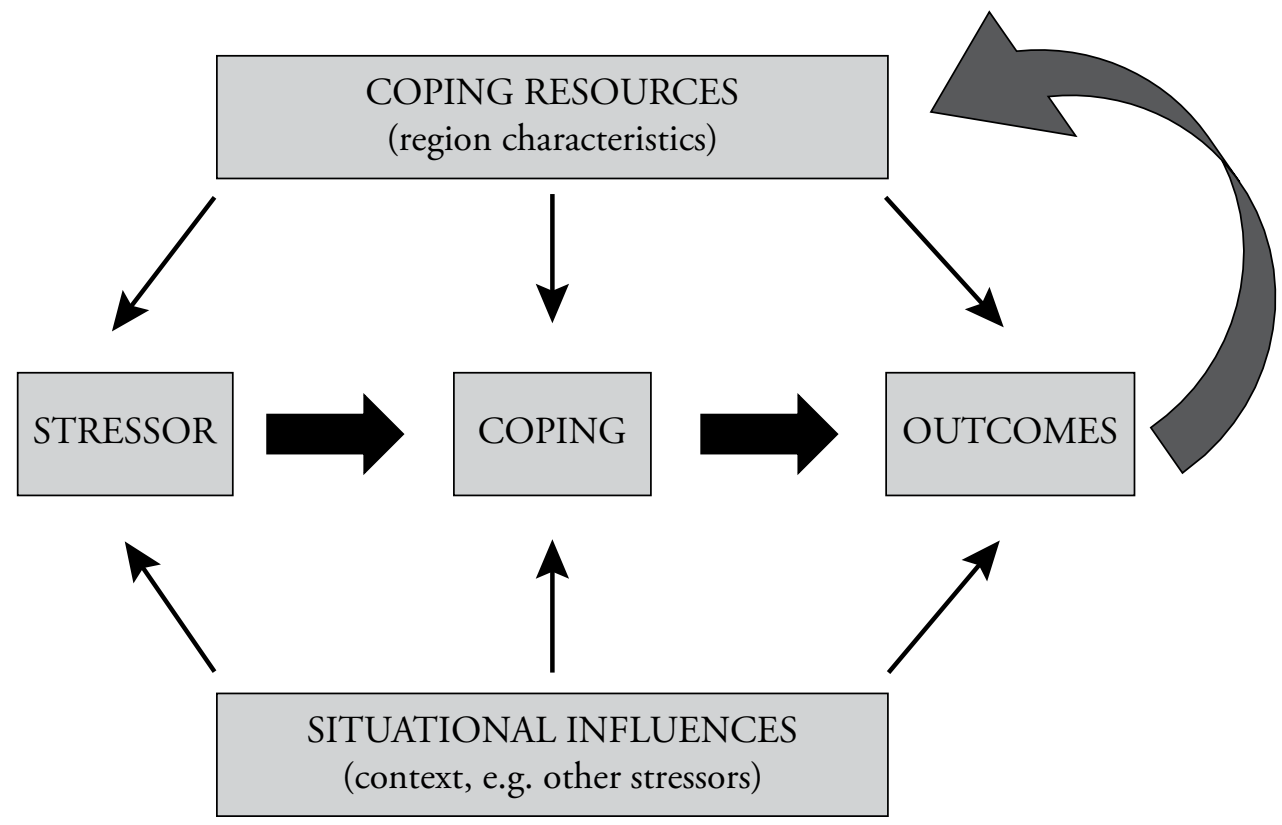

Source: Authors' elaboration, based on DeLongis and Holtzman (2005).

Figure 2 transfers the gist of the coping model to the domain of regional organizations and illustrates possible direct and indirect effects of the stressor, situational influences, and region characteristics on the coping process. Stress situations facing regional organizations are likely to be particularly challenging when they are novel (the regional organization has no previous experience with similar situations), imminent (little time to anticipate and prepare for the situation), enduring (persisting for a longer time), and fraught with uncertainty (about whether and when such a situation will happen and when it will end). Situational influences refer to the economic, political, geostrategic, and security context in which the stressor appears. The severity of a particular stressor varies and may exceed a regional organization's coping capacity when it interacts with other pre-existing, recent, or concurrent stressors. Finally, region characteristics that make a regional organization more resilient or more vulnerable to stress are comparable to the coping resources of an individual. A region with favorable characteristics, such as high level of regionalization, highly institutionalized regional organizations, and a strong regional identity, is better equipped to deal with stress than a region with unfavorable characteristics.

Like individuals, regional organizations face recurrent stress situations during their life cycle. By repeatedly assessing a regional organization's coping process, it is possible to determine the extent to which coping resources change over time. We assume that a feedback effect comes into play: The outcomes of earlier stress situations condition the coping resources in subsequent stress situations, as depicted by the gray arrow in Figure 2. This feedback effect works both ways, that is, it can either strengthen or weaken coping resources (and, concomitantly, eliminate or impose constraints that inhibit the use of these resources). When an earlier stress situation was successfully mitigated, the region might have come out of it strengthened - regional interactions 
might increase, divisions be overcome, an ad hoc crisis resolution mechanism might have been made permanent, and the belief in regionalism among political elites and/or citizens might be stronger than before. In turn, when regional organizations remained on the sidelines or were unsuccessful in trying to respond to a stress situation, a spiral of disintegration might set in. This might also be why, as shown by the studies on the death of IOs, their age has significant effect on the chances of survival (Eilstrup-Sangiovanni 2020; 2021; Debre and Dijkstra 2021a): Older organizations are likely to have accumulated experiences of successful coping with stress.

\section{Research design and methodology}

To investigate how sequences of stress situations play out concretely, we analyze two recent stress situations facing regionalism in South America. The political crisis in Venezuela was originally a domestic process of democratic backsliding, which has had regional repercussions due to massive refugee flows into neighboring countries and repeated mediation attempts by regional organizations. In turn, the Covid-19 pandemic is a global challenge that hit the region as external shock in early 2020. The purpose of this article is not to give a detailed description of these two crises and the policy measures regional organizations have adopted in reaction to them. Rather, we explore how regionalism is shaped by confronting a sequence of stress situations. The two stress situations happened at different moments in time, which allows us to scrutinize whether the outcomes of the first situation conditioned regional organizations' coping resources when facing the second situation.

Our methodological approach thus combines process-tracing as the foundational method of within-case analysis with a sequential analysis (Falleti and Mahoney 2015). The analysis of sequences usually focuses on combinations of factors instead of individual factors. Process-tracing not only allows us to assemble stressors, coping and outcome into a connected sequence and to assess how they were conditioned by coping resources and situational influences, but also to consider the extent to which the outcome of previous coping processes affected the coping resources in a subsequent stress situation (see Figure 2). The two case study sections are organized as follows: we first take stock of regional organizations' coping resources ahead of the stress situation. Second, we study situational influences. As suggested by Lazarus and Folkman (1984, 82-116), each stress situation is discussed together with its contextual properties - its timing and its relation to other recent and concurrent stressors. Finally, we assess how regional organizations coped with the stress situation and which outcomes were produced. Despite analyzing the same components of the coping process for each situation, we don't undertake a synchronous comparison of the two cases but concentrate on their sequential nature, showing that the coping resources ahead of the Covid-19 pandemic were influenced by the outcomes of coping with the political crisis in Venezuela.

While the actions and the fate of individual regional organizations are important, we chose to focus on regionalism, understood as the overall configuration of regional organizations, as our 
unit of analysis - which makes sense in a region like South America, characterized by the frequent creation of new, seemingly redundant and overlapping regional organizations (Weiffen et al. 2013).

\section{Stress situation 1: The political crisis in Venezuela}

South American regionalism is inserted in the global, hemispheric, and subregional context. Regional organizations do not act in an economic-political vacuum but reflect and react to the conditions of the international political economy and changes in the domestic politics of their member states. It is thus not surprising that a complex and enduring stress situation such as the Venezuelan political crisis has had a strong impact on the region.

\section{Coping resources}

Some of the main region characteristics date back to well before the onset of the political crisis in Venezuela (Nolte 2019; 2021b). On the demand side, Latin American regionalism traditionally exhibited comparatively low levels of economic regionalization, as countries have much stronger extra-regional economic connections. Intra-regional trade as a percentage of total trade in general did not surpass 20\%. Regarding fault lines that might constitute an obstacle to regional cooperation, Latin America experienced a low number of inter-state conflicts, and inter-state disputes are mostly resolved through diplomatic or judicial mechanisms. However, in the wake of the "pink tide" of radical left and center-left governments in the first decade of the new millennium, political-ideological tensions started to emerge and have since then reached a level where presidents are unwilling to cooperate with their counterparts if they belong to a different ideological camp. Not only have those ideological fault lines restricted the possibilities of regional cooperation, but regional institutions have become a battlefield for ideological confrontations between governments.

In terms of supply factors, Latin American regionalism has always been characterized by excessive protection of national sovereignty, which was directed outwards (as a protective shield against influences from outside the region), but also against possible interference by partners in regional integration projects. Latin American regionalism exhibits a preference for intergovernmental mechanisms. It is also highly dependent on inter-presidential dynamics and thrived mainly in times of strong presidential leadership and ideological affinities among presidents (Malamud 2015). In the 1990s the environment was conducive to regional political and economic cooperation. Under the neoliberal aegis of the Washington Consensus, center-left and center-right governments shared a common interest in opening their economies and promoting regional integration: Mercosur was founded, and the Andean Community (CAN) was revitalized (transforming its predecessor, the Andean Pact).

In the new millennium, the economic context became less favorable, but political consensus among the left-wing governments of the "pink tide", the emergence of Brazil and, to a lesser extent, 
Venezuela as regional leaders, compensated for the still low economic regionalization. This led to a social and political repositioning of Mercosur and the creation of ALBA (2004), UNASUR (2008), and CELAC (2010), all of which are regional projects with a more political than economic agenda. With its sectoral councils, UNASUR covered a wide range of public policy areas, such as defense, infrastructure and health, and deepened regional cooperation in these areas (Hoffmann 2019; Palestini and Agostinis 2018). The liberal economic right in countries like Chile and Colombia was still in favor of regional cooperation, but with the primarily economic objective to facilitate a better insertion in the global economy. The Pacific Alliance exemplifies this liberal regionalism, designed as a counter-model to more protectionist (Mercosur) or anti-liberal (ALBA) varieties of regionalism. With its creation in 2012, Latin American regionalism became ideologically more fragmented, as liberal and post-liberal projects coexisted.

However, the level of institutionalization remained low. Apart from the 1990s, where the creation of supranational institutions was a fashionable topic, "light regionalism" was the dominant concept in the early years of the $21^{\text {st }}$ century (Sanahuja 2008). While the technical secretariats of Mercosur and the Andean Community are not very strong, the UNASUR secretariat (which no longer exists) was even weaker, and CELAC, ALBA, or the Pacific Alliance have no secretariats at all.

As South American regionalism underwent a process of sub-regionalization, different segments or levels of integration coexisted within the same region. For a certain time, the pluralist architecture of flexible and overlapping organizations facilitated a pattern of cooperative regional governance, characterized by frequent intergovernmental interactions between presidents and ministers and sectoral bureaucratic networks that contributed to policy coordination and the dissemination of regional standards (Nolte 2016). At that time, Latin American political elites proved to be favorable to the implementation of new regional projects as well as the renewal or reorientation of existing ones. Likewise, Latin American citizens overwhelmingly supported regional integration. According to the INTAL / Latinobarómetro surveys, in 2010 and 2017, around 60 percent (2010: 62\%; 2017: 61\%) of Latin Americans were in favor of the political integration of their country with other countries in the region (Barral 2020).

\section{Situational influences}

The Venezuelan political crisis has its origins in the incremental democratic backsliding and increasing polarization under the presidency of Hugo Chávez (1999-2013). After President Nicolás Maduro came to office in 2013, he repeatedly responded to anti-government protests with repression and systematically curtailed the rights of the opposition. Following the opposition victory in the 2015 parliamentary elections, Maduro undertook several moves to neutralize the parliament through a combination of presidential decrees and favorable Supreme Court rulings. In 2016, he suspended a recall referendum intended to remove him from office, and in 2017 he installed a Constitutional Assembly that effectively replaced the parliament. His reelection in 2018, flawed with irregularities, further consolidated his authoritarian rule. Each culmination point 
of the process of democratic backsliding was met with an international outcry and diplomatic condemnation, and between 2013 and 2017, regional organizations undertook several attempts to mediate between government and opposition and to sanction the violations of democratic norms.

However, the crisis and the various mitigation attempts took place in an already difficult regional context. Starting in the early 2010s, Latin American regionalism faced various stressors that affected its resilience. The end of the commodity boom caused growth rates in the region to stagnate. Low oil prices and a drop in oil production due to lack of maintenance and investment plunged the Venezuelan economy into a particularly severe crisis. Economic stagnation also brought a further decrease in economic regionalization. This applied to trade in general and to trade in industrial products in particular, which are of utmost importance for regional integration.

Furthermore, right-wing or center-right governments took over in a growing number of countries that had previously supported the Venezuelan government, including Paraguay in 2012, Argentina in 2015, Brazil after the impeachment of Dilma Rousseff in 2016, and Ecuador in 2017. Maduro became increasingly isolated in the region as the United States also tightened the embargo and pressure on his regime. While the Venezuelan crisis escalated, the ideological polarization between Maduro's external allies and critics intensified. Already under Rousseff, Brazil gradually backed away from its role as a protagonist in the region, and its withdrawal from regional leadership accelerated under Michel Temer's presidency. By the middle of the 2010s the drive for stronger regional cooperation that had inspired especially the foundation of UNASUR had faded.

\section{Coping and outcomes}

In theory, regional organizations were well-equipped to handle the political crisis in Venezuela. The Organization of American States (OAS) has the longest trajectory in supporting and protecting democracy by means of election monitoring, diplomatic mechanisms, and sanctions, as stipulated by the Inter-American Democratic Charter (IADC). Yet, UNASUR and Mercosur also disposed of instruments to protect democracy, creating an overlap of mandates in this area. Especially OAS and UNASUR launched several initiatives in response to the Venezuelan crisis. The OAS repeatedly condemned breaches of democratic norms, and its Secretary General Luis Almagro criticized Maduro on various occasions, attempted to invoke the IADC and impose sanctions on Venezuela. However, decisions about sanctions were blocked by a group of states still supporting Venezuela. Meanwhile, UNASUR, perceived to be more government-friendly, facilitated several rounds of dialogue between government and opposition. OAS and UNASUR became arenas for ideological disputes and cross-institutional strategies of the member countries (Nolte 2018), resulting in a fierce inter-organizational competition in which each organization responded to, and tried to undermine, any initiative of its adversary, and which gave Maduro the opportunity to pit the two organizations against each other. From 2017 onwards, a pluralization and fragmentation of regional organizations' activities took place. Meetings to address the crisis were held by CELAC 
and Mercosur (the latter decided to suspend Venezuela), and the Lima Group emerged as an ad hoc actor to circumvent the stalemate within the OAS.

The Venezuelan political crisis was a watershed that laid open fundamental rifts in the region and ended in a deadlock of main regional organizations. All regional attempts to resolve the crisis eventually failed, and when Venezuelan opposition leader Juan Guaidó declared himself interim president in January 2019, South America no longer played a significant role, but external actors such as the United States, the EU, China, and Russia became the decisive players (Stuenkel 2019). This trajectory is key to understand the dire state of regionalism in South America in the late 2010s. The most striking casualty was UNASUR, whose last summit had been held in 2014 and which gradually stopped working after failing to resolve the Venezuelan crisis. When Ernesto Samper's term as secretary general expired in January 2017, the member countries could not agree on a successor and the position remained vacant. In April 2018, Argentina, Brazil, Chile, Colombia, Paraguay, and Peru suspended their participation in UNASUR and subsequently withdrew from the moribund organization. The governments of Ecuador (under President Lenin Moreno), Bolivia (during the interim presidency of Jeanine Áñez) and Uruguay (after the change of government to Luis Lacalle) later decided to leave as well. While the immediate trigger of this development was the inability of member states to elect a new secretary general, UNASUR's unsuccessful crisis management attempts in Venezuela initiated the decline of the organization (Mijares Chacón and Nolte 2018; Legler and Nolte 2019).

CELAC is another example of paralysis due to political-ideological polarization among member states. At its last summit in the Dominican Republic in January 2017, only 10 presidents participated, but all governments sent representatives. Yet, during a meeting in May 2017 in San Salvador to discuss the crisis in Venezuela, there was no quorum to make decisions. Due to the conflicts within CELAC, the EU-CELAC summit scheduled for October 2017 did not take place, and there was no pro tempore presidency in 2018. Mexico tried to revitalize CELAC when assuming the pro tempore presidency in January 2020, but the Brazilian government suspended its participation for ideological reasons. ALBA also lost its appeal because of the political and economic crisis in Venezuela, which was the organization's main financier. Following the withdrawal of Ecuador and Bolivia, ALBA was reduced to Cuba, Venezuela, Nicaragua, and some Caribbean countries. In sum, the outcome of the Venezuelan crisis left Latin American regionalism severely weakened.

\section{Stress situation 2: The Covid-19 pandemic}

The health crisis caused by Covid-19 presented a major challenge for South America. As a stressor, the global pandemic was novel to the region and fraught with uncertainty. Since Latin America is among the hardest-hit regions in the world in terms of death tolls, it would have been beneficial to act together to contain the spread of the virus. 


\section{Coping resources}

As shown in the previous section, South American regionalism was already in trouble before the pandemic broke out. The repercussions of the Venezuelan crisis produced a negative feedback effect (in line with Figure 2) and made regionalism less resilient to stress by reinforcing disintegrative tendencies. In addition, the demand for regionalism further decreased. Latin American economies had to adjust after the commodity boom had ended. In the period from 2014 to 2019, the annual regional GDP growth rate was only 0.4\% (ECLAC 2020, 8). Moreover, since 2010 Latin America and the Caribbean have been undergoing a process of trade decoupling (ECLAC 2021a, 114). In 2019, intra-regional trade (exports) accounted for less than $15 \%$ of total Latin American trade, and for most subregional groupings, intra-block trade shares are even lower. The average for Mercosur (exports) for the 2018-2019 period was only 11.4\% (Andean Community, 7.2\%; Pacific Alliance, 2.8\%) (ECLAC 2021a, 90).

On the supply side of institutions and regional leadership, the already light institutional structure of Latin American regionalism has weakened even more since the first decade of the $21^{\text {st }}$ century, a process that has been accelerated by the Venezuelan crisis. As a result, the region suffered a "disinvestment of spaces for multilateral policy coordination" (Pauselli 2020). CELAC as an organization representing all Latin America and the Caribbean and UNASUR as an organization that included all South American countries were either paralyzed or in the process of disintegration. The demise of UNASUR also entailed the dismantling of its South American Health Council, resulting in a lack of a coordinated strategy and sub-regional fragmentation of responses to the Covid-19 crisis (Agostinis 2021).

While the presidents of Chile and Colombia invited their South American counterparts to Santiago in 2019 to create a new forum called PROSUR (Forum for the Progress of South America), this has an even lighter institutional structure than previous cooperation projects. Like CELAC, it is not a regional organization but a regional forum whose survival depends on a government calling a summit and enough governments participating. Alongside PROSUR, ad hoc groups like the Lima Group have emerged. In sum, the South American multilateral system is becoming less and less institutionalized. Due to the ephemerality and transitoriness of regional organizations and forums, their decisions are insignificant or not binding.

Notably, secondary powers in the region were crucial in establishing the Lima Group and PROSUR. At least since the mid-2010s, no country has been willing to exercise leadership in regional integration. Among the usual suspects, Mexico and Brazil predominantly focused on domestic affairs, while their foreign policy was oriented towards extra-regional partners. It seems that Brazil wants to dispense with the advantages (and costs) of regional integration, and therefore acts unilaterally to maximize the benefits of its relations with countries outside the region.

While the combination of intergovernmental orientation and inter-presidentialism gave impetus to regional integration in times of ideological affinities among presidents, the same 
factors led to blockades and setbacks in times of polarization and lack of political consensus. The autocratization process under Maduro in Venezuela exacerbated ideological contestations between his remaining supporters and an increasing number of right-wing governments, including Brazil after the 2016 impeachment. Political-ideological polarization not only hinders the development of joint regional projects, but also jeopardizes the survival of existing ones. With the rise of a new populist or "neo-patriotic" right (Sanahuja and López Burian 2020), especially in Brazil after the election of Jair Bolsonaro as president, the constellation has become even more complicated. Whereas the liberal right supported trade-oriented regional organizations to facilitate integration into the world economy, the "anti-globalist" right questions multilateral institutions and agreements. In sum, both authoritarianism on the left and populism on the right constrain the possibilities for regional cooperation.

The more conflictive relations between presidents, the lack of new regional projects and the questioning of some of the existing regional organizations also affected citizen support for regional integration. The INTAL / Latinobarómetro surveys registered a significant decline of 8 percentage points in support for Latin American integration from 2017 (61\%) to 2018 (53\%) (Barral et al. 2020, 7). At only 44\%, Brazil, the South American giant, is among the countries with the lowest popular support for regional integration.

\section{Situational influences}

The Covid-19 pandemic hit Latin America and the Caribbean at a time of great economic vulnerability and weakness. Fragile multilateral institutions, a lack of leadership and ideological distance between countries limited the possibility of reaching concerted policies in terms of regional health governance (Riggirozzi 2020,2). Not only was Covid-19 a stressor of its own for both national politics and regional and global cooperation, it also exacerbated pre-existing stressors. All Latin American economies went through a deep recession in 2020. According to calculations by the Economic Commission for Latin America and the Caribbean (ECLAC 2021b), Latin American GDP contracted by 6.8\% in 2020 (South America -6.3\%). Intra-regional trade fell more sharply than extra-regional trade $(-24 \%)$. ECLAC calculated a regional trade share of $12 \%$, the lowest value since the mid-1980s (ECLAC 2021a, 78).

On the political level, Covid-19 revealed weaknesses in state capacity and political management, and aggravated pre-existing challenges to democracy. The pandemic gave populist leaders the opportunity to attack and circumvent institutional checks and balances and instrumentalize the crisis to deepen ideological polarization and mobilize their supporters. Furthermore, the crisis hardened their reservations towards globalism and multilateralism. The Brazilian president, for example, accused the World Health Organization (WHO) of an ideological bias and even threatened to withdraw from it. Consequently, there was not much political will to cooperate on the regional level to combat the pandemic. 
In terms of power shifts, the pandemic reinforced global geopolitical trends, including the rivalry between the United States and China (Vadell and Rubiolo 2020). China reacted swiftly to its loss of face due to the policy of disinformation when the pandemic initially broke out. Being the first country to recover from the economic consequences of the Covid-19 crisis, Chinese demand for raw materials is helping Latin American economies. In what became known as "mask diplomacy", the Chinese government used soft power resources, for example provision of medical supplies and equipment, granting of cheap loans and, since 2021, the delivery (and donation) of vaccines to Latin American countries.

The successful containment of the pandemic in China contrasted with the disastrous record of the United States in 2020, which resulted in a loss of prestige for the United States in Latin America and at the same time, fueled the US-Chinese rivalry. President Trump blamed China for the spread of the virus and found support for his strategy of "China bashing" in Latin America (particularly in the Brazilian government). Thus, the Covid-19 crisis became an arena in which the United States and China were waging their conflict. The United States pursued a policy of economic containment towards China in Latin America, trying to bring the region back under its influence. While it may be desirable to practice a policy of active non-alignment by keeping an equal distance from Washington and Beijing and their geopolitical and geo-economic rivalry, as proposed by Fortín et al. (2020), this strategy is probably not viable due to the lack of cooperation and consensus among Latin American governments.

\section{Coping and outcomes}

From an optimistic perspective, it can be affirmed that regional disintegration, which culminated in the withdrawal of almost all member countries from UNASUR, did not continue after the Covid-19 pandemic hit. Instead, there were efforts to reactivate CELAC, and some initiatives in Mercosur, the Andean Community, and the Central American Integration System to exchange information and create support networks in the face of the pandemic (Bianculli 2020; Pauselli 2020; Legler 2021). The Pan American Health Organization (PAHO) also fulfilled its role. Regional organizations with stronger institutionalization, a more technical orientation and less political polarization functioned even during the Covid-19 crisis (Ruano and Saltalamacchia 2021). Yet, the expectations that health might become an engine of renewed regional cooperation, and that Latin America and the Caribbean would join forces to confront Covid-19, for example regarding the production, purchase, and distribution of vaccines, have so far only been met to a limited extent.

In line with our argument about the relevance of coping resources and feedback effects, it seems that the "model of regionalism" (Briceño-Ruiz 2020, 35) and "regional health governance modes" (Agostinis and Parthenay 2021) - that is, structure, mandate(s) and past experiences of coping with stress - mattered. The Central American Integration System (SICA) and the Caribbean Community (CARICOM) became revitalized in coping with the challenges of Covid-19. Both 
organizations have a history (and joint learning experience) in emergency management, especially of natural and environmental disasters, which includes close cooperation to attract and channel external resources to the region (Agostinis and Parthenay 2021; Parthenay 2021). In turn, in South America regional organizations were too weak to provide a coordinated response to the pandemic, and regional leadership was absent. Worse still, there was negative leadership: the presidents of the two largest Latin American economies - Brazil and Mexico - mismanaged the pandemic response domestically. While Mexico during its pro tempore presidency of CELAC at least tried to put the issue on the regional agenda, Brazil renounced any claim to regional leadership on the Covid-19 crisis, thus turning into an obstacle to regional cooperation. The Covid-19 crisis ruthlessly exposed the structural deficits of South American regionalism - its fragmentation and, despite a wide variety of common interests and threats, the absence of an effort of regional convergence (Ríos Sierra 2020, 220). There is a risk that following the pandemic, South America's weight in the world economy will continue to decline and its role will be limited to that of a supplier of raw materials. In that case, regional integration would be more difficult.

\section{Conclusion}

In the period in focus, South American regionalism underwent a gradual process of exhaustion and decay. Two successive stress situations, the Venezuelan political crisis and the Covid-19 pandemic, further weakened the coping resources of a region whose characteristics had already become less resistant to stress and more favorable to disintegrative tendencies. According to Faletti and Mahoney's (2015, 220-222) typology of processes, we found a "self-eroding process" where one stress situation fed into the next and diminished or undermined prior coping resources.

Looking beyond South America, our analytical framework helps to explore how regional organizations in different regions of the world are influenced by stress situations. Our recourse to a psychological perspective provided an original set of theoretical concepts for understanding how regional organizations cope with stress. We have shown how recurrent stress situations produce feedback effects on coping resources, so that successes and failures in coping with earlier stress situations affect the reaction to later ones. However, stressors do not necessarily set off self-eroding processes, but could also contribute to a "self-amplifying process" (Faletti and Mahoney 2015) of regional integration. In theory, stressors like a political crisis in the region or a global pandemic increase the demand for regional cooperation. Neo-functional theories assumed that a crisis may incentivize a group of countries to embark on an integration process, and that successful crisis management in existing regional organizations may induce progress toward a higher stage of integration (Dosenrode 2012). In the past, this also happened in South America, for example when Mercosur and UNASUR adopted democracy clauses in response to political crises in one of their member states. 
The current situation in South America, however, is adverse for regional cooperation and integration. Political-ideological polarization and incompatible ideas about the direction of regional cooperation contributed to the decline of regionalism. Likewise, the pushback against multilateralism from right-wing populist presidents (Sanahuja and López Burian 2020), especially in Brazil, makes closer cooperation difficult. At present there is little evidence that ideological positions are converging, and no regional leader willing to promote new regional projects or to revitalize the paralyzed ones. The lack of regional leadership and visions for the future of regionalism is reflected, as already mentioned, in decreasing popular support for regional integration. Although the disintegration symbolized by UNASUR has not advanced further, the question remains as to whether Latin American regionalism is sufficiently prepared for the challenges of the post-Covid-19 world. The stressors that fueled the disintegration process have not yet gone away and have seriously harmed the region's coping resources.

The observations that political-ideological polarization made regional organizations more vulnerable to stress and that more technical organizations reacted better to the Covid-19 crisis triggered a debate on how Latin American regionalism can be revived and made more resilient. It seems to be consensual that a restart of regional cooperation in Latin America should have a strong technical orientation (Actis and Malacalza 2021; Merke et al. 2021; Nolte 2021a). A “technical-scientific multilateralism” (Legler 2021) based on functional cooperation could help to sidestep political-ideological disagreements among states (Ruano and Saltalamacchia 2021). These proposals coincide with research on crisis management by IOs which suggests that technical, expertise-oriented organizations are more autonomous and less affected by political contestations among member states than political organizations (Olsson and Verbeek 2018). They also coincide with recent studies on death and survival of IOs which show that technical organizations have lower overall mortality and are less vulnerable to geopolitical shocks than non-technical organizations (Eilstrup-Sangiovanni 2021).

However, even more technically oriented regional organizations are not immortal; they will be exposed to stress and may have to work in a region with unfavorable characteristics. Our analytical framework is applicable to different regions and different types of regional organizations. It helps to trace how the process of coping with stress is conditioned by coping resources (i.e., region characteristics) and situational influences, and it exposes the extent to which the outcomes of earlier coping processes affect the coping resources in subsequent stress situations.

\section{Acknowledgements}

Earlier versions of this article were presented during the lecture series "Regionalismo e blocos regionais: Desafios atuais" of the Observatório do Regionalismo, São Paulo, and at a conference of the International Relations working group of the German Association for Latin American Studies (ADLAF), both in December 2020. We thank the participants of those events as well as Will Brown and Simon Usherwood for their helpful and inspiring comments. 


\section{References}

Actis, Esteban and Bernabé Malacalza. "Las políticas exteriores de América Latina en tiempos de autonomía líquida." Nueva Sociedad 291 (2021): 114-126. https://nuso.org/articulo/ las-politicas-exteriores-de-america-latina-en-tiempos-de-autonomia-liquida/. Accessed Aug. 26, 2021.

Agostinis, Giovanni. "COVID-19, the Crisis of South American Regionalism, and the Relevance of Regional Institutions for Global Health Governance.” Forum: COVID-19 and IR Scholarship: One Profession, Many Voices. International Studies Review 23, no. 2 (2021): 316-321. doi: https://dx.doi.org/10.1093\%2Fisr\%2Fviab004

Agostinis, Giovanni and Kevin Parthenay. "Exploring the determinants of regional health governance modes in the Global South: A comparative analysis of Central and South America." Review of International Studies (2021): 1-23. doi: https://doi.org/10.1017/S0260210521000206.

Barral Verna, Ángeles, Ana Inés Basco and Paula Garnero. Entre luces y eclipses: la opinión de los latinoamericanos sobre democracia, instituciones e integración regional. Nota técnica No. 1906. Washington DC: Banco Interamericano de Desarrollo, 2020.

Bianculli, Andrea. COVID-19: An Opportunity for Regional Cooperation in Latin America? Bruges: UNU-CRIS, 2020, http://cris.unu.edu/coronavirus-opportunity-latin-america. Accessed Aug. 26, 2021.

Börzel, Tanja A. and Thomas Risse. "Regionalism under Stress: A Comparative Perspective." In Regionalism under Stress: Europe and Latin America in Comparative Perspective, edited by Detlef Nolte and Brigitte Weiffen, 34-46. London/New York: Routledge, 2021.

Briceño-Ruiz, José. “Da crise da pós-hegemonia ao impacto da COVID-19. O impasse do regionalismo latinoamericano." Revista Cadernos de Campo 29 (2020): 21-39. doi: https://doi.org/10.47284/2359-2419.2020.29.2139

Debre, Maria Josepha and Hylke Dijkstra. "Institutional design for a post-liberal order: why some international organizations live longer than others." European Journal of International Relations 27, no. 1 (2021a): 311-339. doi: https://doi.org/10.1177/1354066120962183

Debre, Maria Josepha and Hylke Dijkstra. "COVID-19 and Policy Responses by International Organizations: Crisis of Liberal International Order or Window of Opportunity?” Global Policy (2021b). doi: https://doi.org/10.1111/1758-5899.12975

DeLongis, Anita and Susan Holtzman. "Coping in Context: The Role of Stress, Social Support, and Personality in Coping." Journal of Personality 73, no. 6 (2005): 1633-56. doi: https://doi.org/10.1111/j.1467-6494.2005.00361.x

Dosenrode, Søren. "Crisis and Regional Integration: A Federalist and Neo-Functionalist Perspective." In Regions and Crises. New Challenges for Contemporary Regionalisms, edited by Lorenzo Fioramonti, 13-30. Basingstoke: Palgrave Macmillan, 2012. 
ECLAC. Report on the economic impact of coronavirus disease (COVID-19) on Latin America and the Caribbean (LC/TS.2020/45). Santiago de Chile: Economic Commission for Latin America and the Caribbean, 2020. https://www.cepal.org/en/publications/45603report-economic-impact-coronavirus-disease-covid-19-latin-america-and-caribbean. Accessed Aug. 26, 2021.

ECLAC. International Trade Outlook for Latin America and the Caribbean, 2020 (LC/PUB.2020/21-P). Santiago de Chile: Economic Commission for Latin America and the Caribbean, 2021a. https:/www.cepal.org/en/publications/46614-international-tradeoutlook-latin-america-and-caribbean-2020-regional-integration. Accessed Aug. 26, 2021.

ECLAC. The Recovery Paradox in Latin America and the Caribbean. Special report Covid-19, No. 11. Santiago de Chile: Economic Commission for Latin America and the Caribbean, 2021b. https://repositorio.cepal.org/bitstream/handle/11362/47059/1/S2100378_en.pdf Accessed Aug. 26, 2021.

Eilstrup-Sangiovanni, Mette. "Death of international organizations. The organizational ecology of intergovernmental organizations, 1815-2015.” Review of International Organizations 15, no. 2 (2020): 339-370. doi: https://doi.org/10.1007/s11558-018-9340-5

Eilstrup-Sangiovanni, Mette. "What kills international organisations? When and why international organisations terminate.” European Journal of International Relations 27, no. 1 (2021): 281-310. doi: https://doi.org/10.1177/1354066120932976

Falleti, Tulia G. and James Mahoney. “The Comparative Sequential Method.” In Advances in Comparative-Historical Analysis, edited by James Mahoney and Kathleen Thelen, 211-37. Cambridge: Cambridge University Press, 2015.

Fioramonti, Lorenzo, ed. Regions and Crises. New Challenges for Contemporary Regionalisms. Basingstoke: Palgrave Macmillan, 2012.

Fortín, Carlos; Jorge Heine, and Carlos Ominami. "Latinoamérica: no alineamiento y la segunda Guerra Fría.” Foreign Affairs Latinoamérica 20, no. 3 (2020): 107-115.

Gildea, Ross J. "Psychology and Aggregation in International Relations." European Journal of International Relations (2020): 1-18. doi: https://doi.org/10.1177/1354066120938830.

Gray, Julia. "Life, Death, or Zombie? The Vitality of International

Organizations." International Studies Quarterly 62, no. 1 (2018): 1-13. doi: https://doi.org/10.1093/isq/sqx086

Hoffmann, Anne Marie. Regional Governance and Policy-Making in South America. Basingstoke: Palgrave Macmillan, 2019.

Kertzer, Joshua D. and Dustin Tingley. "Political Psychology in International Relations: Beyond the Paradigms." Annual Review of Political Science 21 (2018): 319-39. doi: https://doi.org/10.1146/annurev-polisci-041916-020042

Lazarus, Richard S. Stress and Emotion: A New Synthesis. New York, NY: Springer, 1999. Lazarus, Richard S. and Susan Folkman. Stress, Appraisal and Coping. New York, NY: 
Springer, 1984.

Legler, Thomas. "Presidentes y orquestadores: La gobernanza de la pandemia de Covid-19 en las Américas.” Foro Internacional 61, no. 2 (2021): 333-85. doi: https://doi.org/10.24201/fi.v61i2.2833

Legler, Thomas and Detlef Nolte. "Venezuela: la protección regional multilateral de la democracia." Foreign Affairs Latinoamérica 19, no. 2 (2019): 43-51.

Malamud, Andrés. "Presidentialist Decision Making in Latin American Foreign Policy: Examples from Regional Integration Processes." In Routledge Handbook of Latin America in the World, edited by Jorge I. Domínguez and Ana Covarrubias, 112-23. New York: Routledge, 2015.

Melo, Daniella da S.N. de and Maria Papageorgiou. "Regionalism on the Run: ASEAN, EU, AU and MERCOSUR responses amid the Covid-19 Crisis". Partecipazione \& Conflitto 14, no. 1 (2021): 57-78. doi: https://doi.org/10.1285/i20356609v14i1p57

Merke, Federico, Oliver Stuenkel, and Andreas E. Feldmann. Reimagining Regional Governance in Latin America, Washington DC: Carnegie Endowment for International Peace 2021, https://carnegieendowment.org/2021/06/24/reimagining-regionalgovernance-in-latin-america. Accessed Aug. 26, 2021.

Mijares Chacón, Víctor M. and Detlef Nolte. "Regionalismo posthegemónico en crisis ¿Por qué la Unasur se desintegra?” Foreign Affairs Latinoamérica 18, no. 3 (2018): 105-112.

Nolte, Detlef. "Regional Governance from a Comparative Perspective.” In Economy, Politics and Governance. Challenges for the 21st Century, edited by Víctor M. González-Sánchez, 1-16. New York: Nova Science Publishers, 2016.

Nolte, Detlef. "Costs and Benefits of Overlapping Regional Organizations in Latin America: The Case of the OAS and UNASUR." Latin American Politics and Society 60, no. 1 (2018): 128-53. doi: https://doi.org/10.1017/lap.2017.8

Nolte, Detlef. "Lo Bueno, Lo Malo, Lo Feo y Lo Necesario: Pasado, Presente y Futuro Del Regionalismo Latinoamericano." Revista Uruguaya de Ciencia Politica 28, no. 1 (2019): 131-56. doi: https://doi.org/10.26851/rucp.28.1.5

Nolte, Detlef. "From the summits to the plains: The crisis of Latin American Regionalism.” Latin American Policy 12, no.1 (2021a): 181-192. doi: https://doi.org/10.1111/lamp.12215

Nolte, Detlef. “The Pacific Alliance: Regionalism without Stress?” In Regionalism under Stress: Europe and Latin America in Comparative Perspective, edited by Detlef Nolte and Brigitte Weiffen, 150-67. London/New York: Routledge, 2021b.

Nolte, Detlef and Brigitte Weiffen, eds. Regionalism under Stress: Europe and Latin America in Comparative Perspective. London/New York: Routledge, 2021.

Olsson, Eva-Karin and Bertjan Verbeek. "International Organisations and Crisis Management: Do Crises Enable or Constrain IO Autonomy?" Journal of International Relations and Development 21, no. 2 (2018): 275-99. 
doi: https://doi.org/10.1057/s41268-016-0071-z

Palestini, Stefano and Giovanni Agostinis. "Constructing Regionalism in South

America: The Cases of Sectoral Cooperation on Transport Infrastructure and

Energy." Journal of International Relations and Development 21, no. 1 (2018): 46-74. doi: https://doi.org/10.1057/jird.2015.15

Parthenay, Kevin. "Aliarse (regionalmente) contra Covid-19: SICA y CARICOM.” Foro Internacional 61, no. 2 (2021): 387-425. doi: https://doi.org/10.24201/fi.v61i2.2834 Pauselli, Gino. COVID-19 in Latin America: Perspectives from Multilateral Organizations and International Cooperation. Muscatine, Iowa: Stanley Center for Peace and Security/ CRIES, 2020, https://stanleycenter.org/wp-content/uploads/2020/08/DPMVACOVID-19-LatinAmerica-MultilateralOrganizationsCoop-Pauselli-720.pdf. Accessed Aug. 26, 2021.

Riggirozzi, Pía. Coronavirus y el desafio para la gobernanza regional en América. Análisis Carolina 12/2020. Madrid: Fundación Carolina, 2020, https://www.fundacioncarolina. es/wp-content/uploads/2020/03/AC-12.2020.pdf. Accessed Aug. 26, 2021.

Ríos Sierra, Jerónimo. "La inexistente respuesta regional a la COVID-19 en América Latina." Geopolitica(s) 11, no. especial (2020): 209-222. doi: https://doi.org/10.5209/geop.69324 Ruano, Lorena and Natalia Saltalamacchia. "Latin American and Caribbean Regionalism during the Covid-19 Pandemic: Saved by Functionalism?” The International Spectator 56, no. 2 (2021): 93-113. doi: https://doi.org/10.1080/03932729.2021.1900666

Sanahuja, José A. “Del 'regionalismo abierto' al 'regionalismo post-liberal'. Crisis y cambio en la integración regional en América Latina." In Anuario de la Integración Regional de América Latina y el Gran Caribe $N^{\circ}$ 7, año 2008-2009, edited by Laneydi Martínez Alfonso, Lázaro Peña and Mariana Vazquez, 11-54. Buenos Aires: CRIES, 2008. Sanahuja, José A. and Camilo López Burian. “The new Latin American neo-patriotic far-right: reactionary internationalism and its challenge to the international liberal order." Revista Conjuntura Austral 11, no. 55 (2020): 22-34. doi: http://dx.doi.org/10.22456/2178-8839.106956

Saurugger, Sabine and Fabien Terpan, eds. Crisis and Institutional Change in Regional Integration. London/New York: Routledge, 2016.

Stuenkel, Oliver. "How South America Ceded the Field in Venezuela." Foreign Affairs, 31 January 2019. https://www.foreignaffairs.com/articles/south-america/2019-01-31/howsouth-america-ceded-field-venezuela. Accessed Aug. 28, 2021.

Vadell, Javier and Florencia Rubiolo. "China y la economía política de la pandemia en América Latina y el Caribe en la conturbada geopolítica del siglo XXI.” Temas y Debates 24, no. especial (2020): 43-50. doi: https://doi.org/10.35305/tyd.v0i0.481

Von Borzyskowski, Inken and Felicity Vabulas. "Hello, goodbye: When do states withdraw from international organizations?" Review of International Organizations 14, no. 2 (2019): 335-366. doi: https://doi.org/10.1007/s11558-019-09352-2 
Weiffen, Brigitte. "Stress Factors and Their Impact on Regionalism." In Regionalism under Stress: Europe and Latin America in Comparative Perspective, edited by Detlef Nolte and Brigitte Weiffen, 15-33. London/New York: Routledge, 2021. Weiffen, Brigitte, Leslie Wehner and Detlef Nolte. "Overlapping regional security institutions in South America: The case of OAS and UNASUR." International Area Studies Review 16, no. 4 (2013): 370-389. doi: https://doi.org/10.1177/2233865913503466 